\title{
АРХЕОЛОГИЯ
}

\section{The Bronze Horse Bit from the Central Burial Chamber of the Kurgan Arzhan-1}

\author{
V. Horvath
}

For citation: Horvath V. The Bronze Horse Bit from the Central Burial Chamber of the Kurgan Arzhan-1. Vestnik of Saint Petersburg University. History, 2018, vol. 63, issue 4, pp. 1221-1237. https://doi. org/10.21638/11701/spbu02.2018.413

The Arzhan-1 kurgan plays a very important role in the research regarding the early Scythian age in Inner Asia and Kazakhstan. To begin with, it is one of the earliest monument to demonstrate the developed Scythian Triad. In the article, the authors will be examining the unusually structured bronze horse - bit found in the central chamber of the kurgan. The external ring of one of the parts of this bit seems to be of an elongated stirrup shape with signs of a supplementary hole. A thorough examination of the object has revealed that the two pieces of the bit are completely different from each other, not only in form but as regards their chemical composition as well. The part with rectangular relief designs in two or more rows along one side of the mouthpiece, is similar to the sets of horse trappings of the classical Novocherkassk type and early Zhabotin period in Eastern Europe dating from the end of $8^{\text {th }}-$ the first half of $7^{\text {th }}$ c. BC. Bronze horse bits with the "pawn shaped" external ring known from Tuva and the mountainous and foothill regions of Altai, at first sight seem similar to the presented form, but were found in the so-called Y-shaped side-structures. When studying their structural characteristics, experts determined that this type of bit and side structure is presumably an imitation of the structure of the inflexible horse-bits. Taking into account all the examined data, the location of the bit within the tomb and the circumstances of the kurgan's excavation, it becomes obvious that the system of relationships characteristic of the Tuva region, the neighboring and further areas in the Scythian Age had begun to develop already in the Arzhan Era.

Veronika Horvath - PhD student, Al-Farabi Kazakh National University, 71, bvd. Al-Farabi, Almaty, 050040, Kazakhstan; scythianworld@mail.ru

Вероника Хорват - PhD докторант, Казахский национальный университет им. аль-Фараби, Казахстан, 050040, Алматы, пр. Аль-Фараби, 71; scythianworld@mail.ru

The author of the article would like to express her gratitude to the director of the Aldan-Maadyr, National Museum of the Republic of Tyva, Bicheldej Kadir-ool Alekseevich; to Mongush Laida Kara-oolovna, the museum's deputy director; to Khovalig Rolanda Biche-oolovna, the museum's chief curator, and to Ayanmaa Ondar Valerievna, a colleague from the archaeological collection of the museum for the opportunity to study the Arzhan-1 kurgan finds and to prepare a publication.

(c) Санкт-Петербургский государственный университет, 2018 
Keywords: Arzhan-1, mouth-pieces of the classical Novocherkassk type, early Zhabotin, Tuva, Altai, Eastern Aral area.

\section{Бронзовые удила из центральной камеры кургана Аржан-1}

\section{B. Хорват}

For citation: Horvath V. The Bronze Horse Bit from the Central Burial Chamber of the Kurgan Arzhan-1. Vestnik of Saint Petersburg University. History, 2018, vol. 63, issue 4, pp. 1221-1237. https://doi. org/10.21638/11701/spbu02.2018.413

Курган Аржан-1 занимает очень важное место в изучении начальной фазы скифской эпохи Центральной Азии и Казахстана. Прежде всего он является одним из самых ранних памятников, где представлена сформировавшаяся скифская триада. В данной статье автор анализирует своеобразные бронзовые удила, которые были найдены в центральной камере кургана. Одно из звеньев этих удил имеет стремечковидное внешнее со следами дополнительного отверстия окончание, а другое - круглое. Примечательно, что звенья различаются между собой не только формой, но и химическим составом металла. Ближайшие аналоги указанных удил по орнаментам в виде двухрядных прямоугольных рельефных выступов встречаются среди уздечных наборов классического Новочеркасского типа и раннежаботинского периода в Восточной Европе, датируемых концом VIII - первой половиной VII в. до н. э. Экземпляры с «пешковидным» внешним кольцом, которые известны из Тувы и предгорных регионов Алтая, на первый вгляд кажутся подобными представленной форме, но они сочетаются с У-образными бронзовыми псалиями. Представляется, если опираться на все данные анализированных памятников, их контекст в погребальной камере, в том числе на особенности устройства кургана Аржан-1, этот памятник не может быть датирован ранее третьей четверти VIII в. до н. э. То есть уже в аржанский период началось возникновение системы взаимоотношений с прилегающими и отдаленными регионами, характерной для Тувы в раннескифское время. Однако по данным результатов радиоуглеродных анализов комплекс определяется концом IX - началом VIIIв. до н.э. Соответственно, возникает вопрос о том, что бронзовые удила не входили в курган, а попали туда позже с новым впускным подзахоронением. Но данное предположение невозможно подтвердить, поскольку сохранность кургана была сильно нарушена.

Ключевые слова: Аржан-1, удила классического Новочеркасского типа, ранний Жаботинский период, Тува, Алтай, Восточное Приаралье.

\section{Introduction}

The Scythian-Saka tribes played an important role in the history of the Eurasian region. That is why archaeologists always devote special attention to the study of these people. One of the most definitive excavation sites in regards to this era is the Arzhan-1 kurgan, where the elements of the so-called Scythian Triad appear in their fully-fledged form.

After the excavation of the kurgan, many smaller publications, in addition to the 1980 Russian $^{1}$ and German monographs ${ }^{2}$, dealt with certain interesting characteristics of the kurgan ${ }^{3}$.

${ }^{1}$ Gryaznov M.P. Arzhan - "tsarskii" kurgan ranneskifskogo vremeni. Leningrad, 1980.

2 Gryaznov M.P. Der Großkurgan von Aržan in Tuva, Südsibirien. München, 1984.

3 Gryaznov M.P.: 1) K voprosu o slozhenii kul'tur skifo-sibirskogo tipa v sviazi s otkrytiem kurgana Arzhan // KSIA. 1978. N 154. P.9-18; 2) Nachal'naia faza razvitiia skifo-sibirskikh kul'tur // Arkheologi- 
However, the site has not been fully processed to this day. Unfortunately, this causes a number of difficulties as far as the excavation site as well as the interpretation of its cultural role in the region of Inner Asia are concerned. Given the limited format of this article. the author will examine one small but important fraction of the complex - a horse-bit - discovered in the central chamber, an artifact which raises several questions about the relationships between the early nomadic horsemen tribes of Inner Asia and Eastern Europe.

\section{The circumstances of the excavation of the kurgan}

The fact that the kurgan had been disturbed and robbed ${ }^{4}$ on several occasions was obvious even before digging began at the site. This was aggravated by the highway from Turan to the village of Tarlyk, intersecting the $\operatorname{kurgan}^{5}$ (fig. 1). A small chapel was built on the side of the road roughly above the central chamber, near which there is a spring. Later, the Tuvans built a temple here which stood until the 1920s. In the 1940s and 1950s, L. R. Kyzlasov inspected the area, assessed the site and wrote a description of it ${ }^{6}$. According to the notes of M.P. Griaznov, the spring by the road had run dry by the beginning of the 1960s. At the same time, due to construction in the neighboring villages, the size and number of the external stone structures of the kurgan had decreased ${ }^{7}$.

In 1971, in the first phase, the excavation was began in the approximate area of the central chamber compartment. In this sector of the compartment, the corners of the

ia Iuzhnoi Sibiri. 1983. Iss. 12. P.3-18; Bokovenko N. A.: 1) Nachal'nyi etap kul'tury rannikh kochevnikov Saiano-Altaia (po materialam konskogo snariazheniia). Diss. ... kand. ist nauk. Leningrad, 1986; 2) Problemy genezisa pogrebal'nogo obriada rannekochevnicheskoi znati Tsentral'noi Azii // Elitnie kurgany stepei Evrazii v skifo-sarmatskuiu epokhu / ed. by A. Iu. Alekseev. St. Petersburg, 1994. P.41-48; The Origin of Horse Riding and the Development of Central Asian Nomadic Riding Harnesses // J.D. Kimball. Kurgans, Ritual Sites and Settlements Eurasian Bronze and Iron Age. BAR International Series 890. Oxford, 2000. P. 304-310; Chlenova N. L.: Eshche raz o date olennogo kamnia iz Arzhana // KSIA. 1993. Iss. 204. P. 24-29; Tsentral'naia Aziia i skify I. Data kurgana Arzhan i ego mesto v sisteme kul'tur skifsogo mira. Moscow, 1997; Marsadolov L. S.: 1) Tkani iz kurgana Arzhan v Tsentre Azii // Piatie istoricheskie chteniia pamiati M.P. Gryaznova. Tezisy dokladov Vserossiiskoi nauchnoi koferentsii (Omsk, 19-20 okt. 2000 g.). Omsk, 2000. P. 72-75; 2) Rekonstruktsiia olennogo kamnia iz kurgana Arzhan-1 // Vremia i kul'tura v arkheologo-etnograficheskikh issledovaniiakh drevnikh i sovremennykh obshchestv Zapadnoi Sibiri i sopredelnykh territorii: problemy interpretatsii i rekonstruktsii. Materialy XIV Zapadno-Sibirskoi arkheologo-etnograficheskoi konferentsii. Tomsk, 2008. P.60-64; Savinov D. G.: 1) Rekonstruktsiia pogrebal'nogo kompleksa kurgana Arzhan, ego komponenty i analogii // Severnaia Evraziia ot drevnosti do Srednevekov'ia. Tezisy konferentsii k 90-letiiu so dnia rozhdeniia M. P. Gryaznova / ed. by B. P. Shilov. St. Petersburg, 1992. P. 108114; 2) Rannie kochevniki Verkhnego Eniseia. Arkheologicheskie kul'tury i kul'turogenez. St. Petersburg, 2002. P.37-69.

${ }^{4}$ According to the materials of M.P. Gryaznov's excavation archives, all burials and horse skeletons, even in the other chambers, were laid to rest at the bottom of the chamber where the ground level once was. Gryaznov believed that the whole complex was built during one stage. This is confirmed by the fact that the wooden building originally reached the 3-4 beam height (about 2,5-3 m), which would have made it impossible to bury there after the completion of the construction. Gryaznov M.P. Otchet o raskopkakh kurgana Arzhan v 1971-1972 gg. // Nauchno-otraslevoy arkhiv Instituta Arkheologii Rossiiskoy Akademii Nauk (Nauchnyi arkhiv IA RAN). R-1 № 4833. 1973. P. 12-13. The authors express their gratitude to N. A. Bokoveno, a researcher at the Institute for the History of Material Culture (Saint Petersburg) for clarifying and confirming information on the burials.

${ }^{5}$ Gryaznov M.P. Arzhan - "tsarskii" kurgan... Ill.1.

${ }^{6}$ Kyzlasov L. R. Drevniaia Tuva (ot paleolita do IX v.). Moscow, 1979. P. 34.

7 Gryaznov M.P // Nauchnyi arkhiv IA RAN. R-1. № 4833. 1973. P. 5-7. 


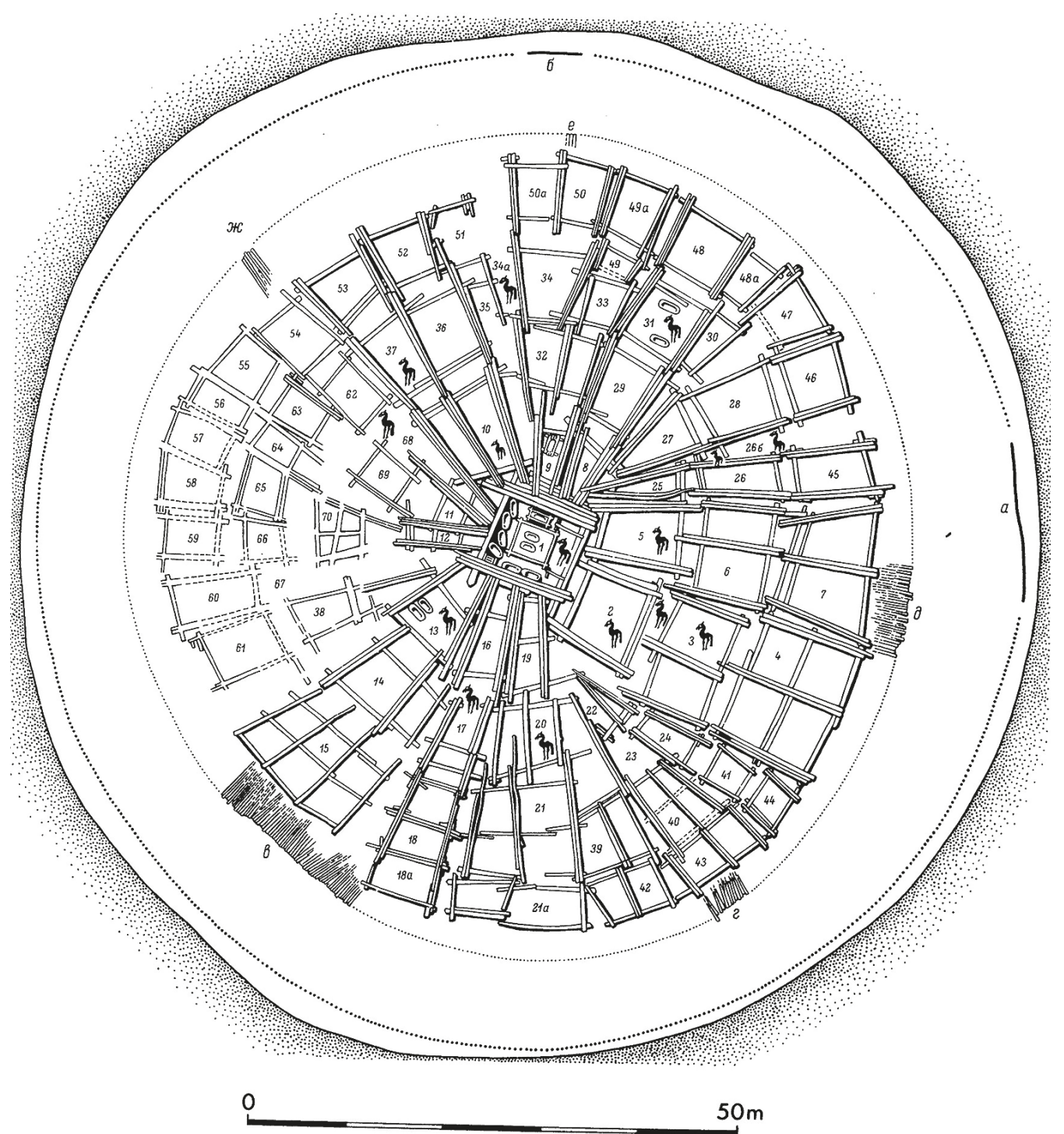

Fig. 1. Map of the wooden construction of the kurgan [Source: Gryaznov M.P. Der Großkurgan... Abb. 3]

1st (central) and 2nd chambers were uncovered. Because most of the central chamber is located under the highway that intersects the kurgan, digging progressed toward the chamber's "unprotected" south-eastern side 8 .

During the excavation, the scattered remains of 6 horse skeletons were found by the eastern wall of the chamber under the beam-framed covering, which indicated that the

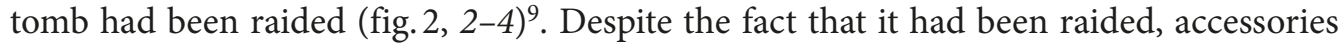

${ }^{8}$ Gryaznov M.P. Arzhan - "tsarskii" kurgan... P. 8.

9 Gryaznov M. P. Otchet o raskopkakh kurgana Arzhan v 1971-1972 gg. P. 17; Gryaznov M. P., Mannaiool M. Kh. Kurgan Arzhan - mogila "tsaria" ranneskifskogo vremeni // UZTNIIIaLI. 1973. Iss. XVI. Ill. 2. 

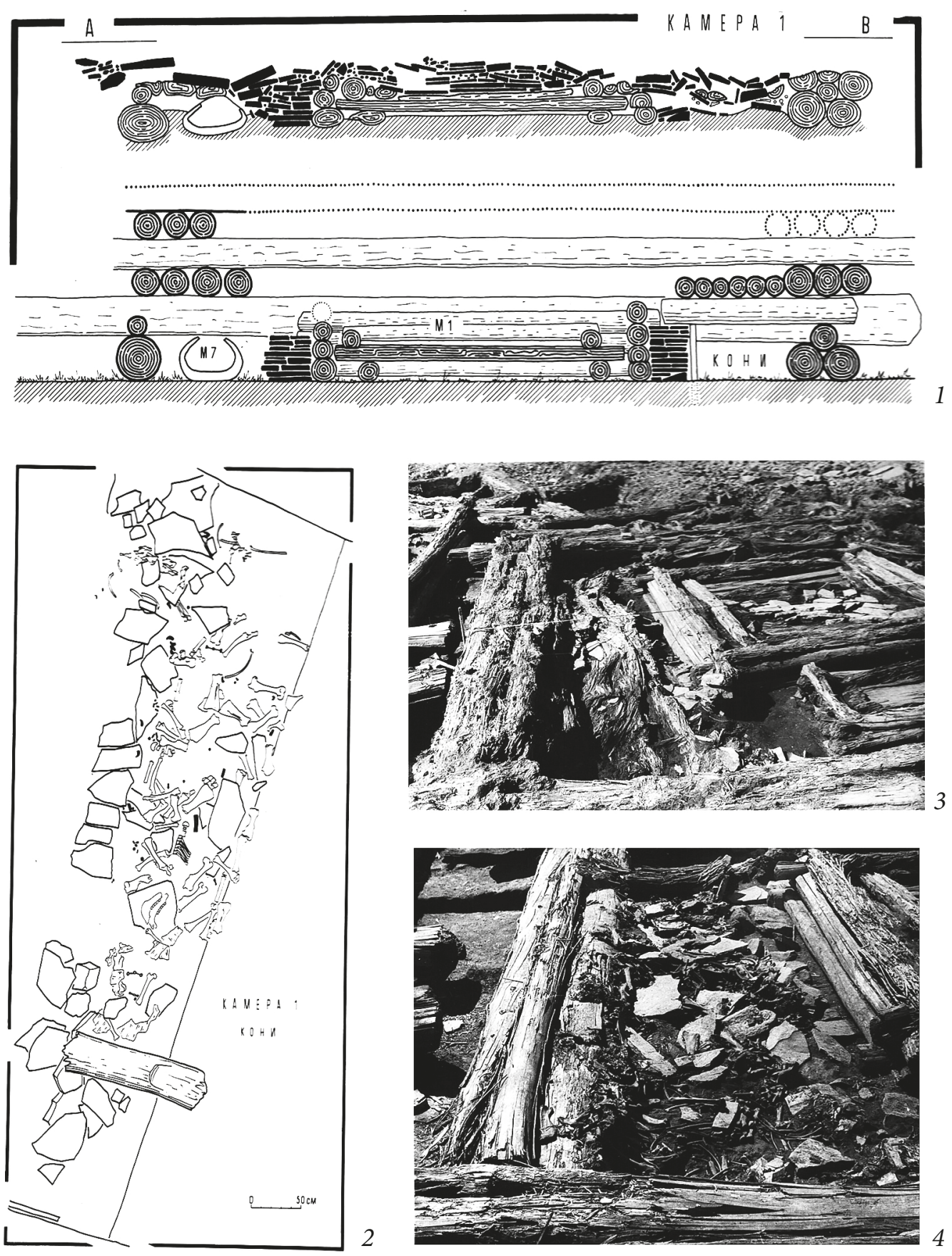

Fig. 2. Horse burials in the central chamber of the Arzhan-1 kurgan: $1-$ cross sections and reconstructions; 2 - location of the horse burials (view from above); 3 - fragments of wooden ceiling over the horse burials (view from north); 4 - horse burials after refining [Source: Gryaznov M.P. Otchet o raskopkakh kurgana Arzhan. P.71, 84-85. 1973] 
of horse tack were discovered, which were made of gold, silver, argillite and tusks of the wild boar, along with three kinds of bits ${ }^{10}$. The first has a smooth mouthpiece and ends in rings, the second has a thick, twisted mouthpiece and its external ring has an additional hole, and the third is of a non-uniform structure. The latter is the main subject of our examination.

\section{Description of the bronze bit}

The bronze bit we have examined (inventory number: KP 5479/24) is made of two parts with different external rings. The first part of the bit has a round cross-section (width: 0,7 cm), a smooth mouthpiece (length: $4 \mathrm{~cm}$ ) and its external (external diameter: $2,7 \mathrm{~cm}$, internal diameter: $1,5 \mathrm{~cm}$ ) and internal (external diameter: $2,1 \mathrm{~cm}$, internal diameter: $1,3 \mathrm{~cm}$ ) fastened in a ring shape (Fig. 3, b-c). The second part of the bit differs entirely from the first. Its round cross-sectioned smooth surface (length: $4,3 \mathrm{~cm}$, width: $0,8 \mathrm{~cm}$ ) is ornamented on one side with etched, rectangular relief patterns in two rows. Its external ring (external diameter: $2,4 \times 1,7 \mathrm{~cm}$, internal diameter: $1,7 \mathrm{x} 1 \mathrm{~cm}$ ) seems to be of an elongated stirrup shape, of which the lower half widens in a trapezoid form, and the signs of a supplementary hole can be seen on the side close to the mouthpiece, which was presumably removed due to an error in molding (fig. 3, d).

Taking into account molding techniques of the Arzhan-Majemir era of the bit ${ }^{11}$, we have attempted to reconstruct the manufacturing phases of the irregularly structured bit in question. First, the symmetrical piece of the bit was made with a double-sided mold. Afterwards, the external, stirrup-shaped end was poured and attached to the relief-ornamented mouthpiece. The asymmetrical component of the bit, ending in rings, was made after the symmetrical component. The structure of the internal rings of the component of the bit is composed of two open rings which were finally merged and welded to the mouthpiece. The spot where the parts of the structure were connected can be clearly seen on the external sides of rings (fig. 3, e).

\section{Morphological analogies}

The nearest parallels to the irregularly structured type of bit we are examining can be found, first of all, in the Arzhan-1 kurgan. Its obvious characteristic is the two rectangular relief-patterns running along one of the sides in two rows. Similar but less refined, reliefs can be found on the mouthpiece of the asymmetric component of the bit-piece ending in rings found in chamber $26 \mathrm{~B}^{12}$. Apart from this, the the mouthpiece of the symmetrical component of the stirrup-ended bit from chambers $31^{13}$ and $37^{14}$ is decorated with the same relief pattern.It is noteworthy that an important aspect that in all three cases the bits are made of different components.

10 Gryaznov M. P. Arzhan - "tsarskii" kurgan... Ill. 10, 12-13.

11 Minasian R. S.: 1) Sposoby lit'ia bronzovykh udil v predskifskoe i skifskoe vremia // Elitnye kurgany stepei Evrazii v skifo-sarmatskuiu epokhu. St. Petersburg, 1994. P. 157-158; 2) Metalloobrabotka v drevnosti i Srednevekov'e. St. Petersburg, 2014. P. 147-149.

12 Gryaznov M.P. Arzhan. Foto i chertezhi raskopok 1973 g. // Nauchnyi arkhiv IA RAN.R-1. N5579a/71. 1974.

13 Ibid. N 5579a/173, first object from above.

14 Ibid. N 5579a/224, second object from above. 

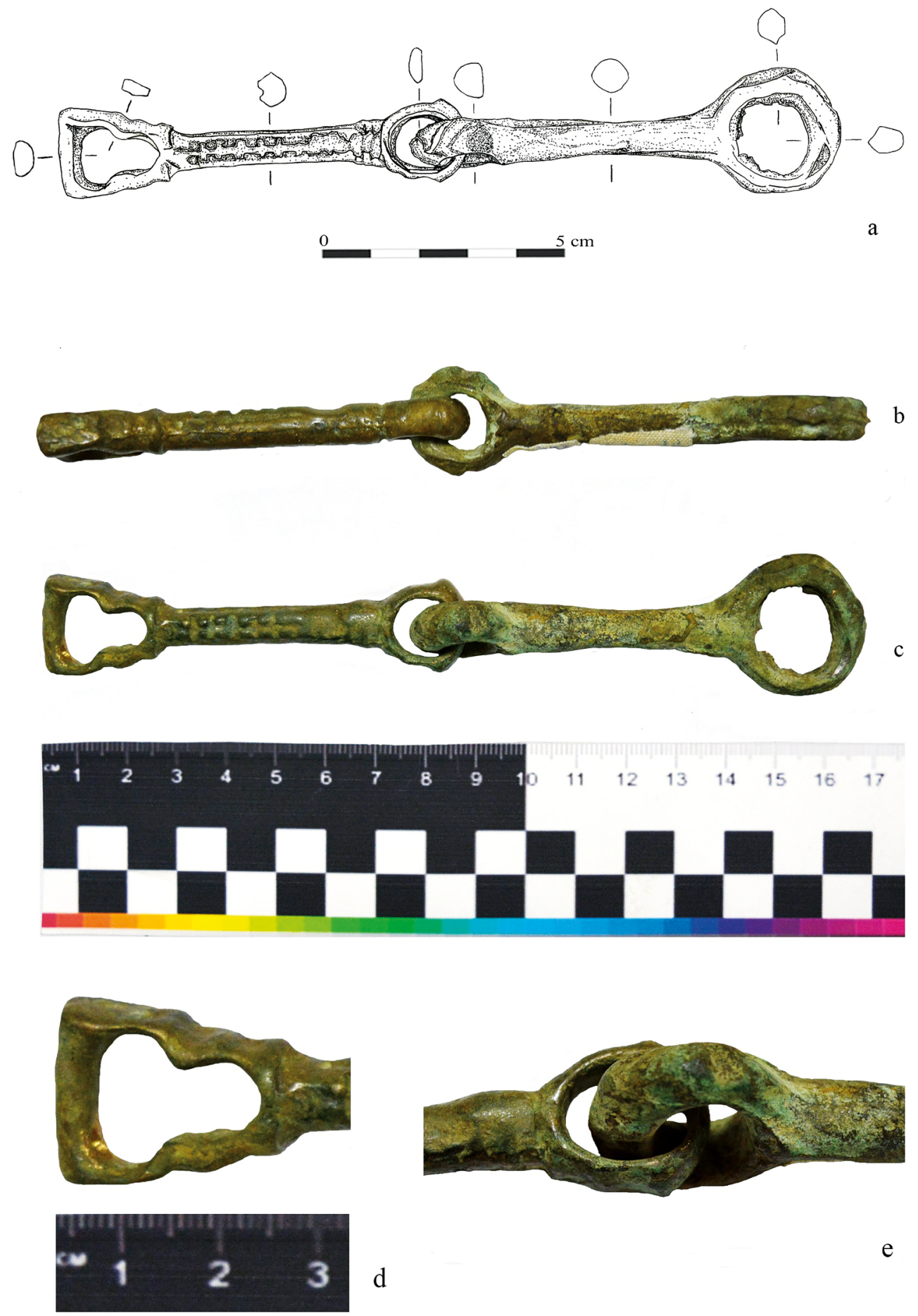

$\mathrm{e}$

Fig. 3. Bronze bit with "pawn" shaped end from the horse burial, central chamber, Arzhan-1 kurgan (National Museum, Republic of Tuva, KP 5479/24 stone 1, 1971; the illustration and photos were made by the author) 
Another bit, the one with less refined work on the reliefs, was found in kurgan 69 of the Uigarak Burial Ground along with bone side-pieces ${ }^{15}$.

However, rectangular relief ornamentation in rows of two or more was more common in the Novocherkassk period and in the intermediary period before the early Scythian period in the Northern Caucasus and the right bank of the Dnieper. As several researchers have already determined, rectangular relief ornamentation appeared in the Eastern European regions in the $2^{\text {nd }}$ half of the $8^{\text {th }}$ century $\mathrm{BC}^{16}$. It is worth referring to the bit with the D-shaped external ring from graves 35 and 38 of the Pshish Burial Ground ${ }^{17}$; the ringed bit of the $2^{\text {nd }}$ collection of the Beliaev Burial Ground ${ }^{18}$, and the stirrup-ended bit from the Psekups Burial Ground's ${ }^{19}$.

The classic Novocherkassk type double-ringed bits are mainly characterized by relief-like ornamentation. The component of the bit of the 2nd grave of the Kamennomost Burial Ground was found with a side-piece with three holes, and also with relief ornamentation on the sides and on a lower end that opens ${ }^{20}$. A similar double-ringed bronze-bit was discovered in the Farsh Burial Ground, grave $14^{21}$, or the Pshish Burial Ground, grave $105^{22}$, along with a stick-like ringed side-piece. The relief-ornamented bit found in the area of the Baksan straights may also be mentioned here ${ }^{23}$. The common characteristic of the bits we have listed is a relatively short, $3-4 \mathrm{~cm}$, mouthpiece.

Further parallels can be drawn with the bit with cross-shaped notched buckles from the disturbed grave near the village of $\mathrm{Bagov}^{24}$, and the bit with the ringed side-piece ending in a spoon form, from grave 18 of the Klin Iar III Burial Ground ${ }^{25}$. Naturally, apart from these, the mentioned double-ringed bits ornamented with rectangular relief patterns do occur in the Novocherkassk excavation site ${ }^{26}$, the 2nd kurgan of the Uashitu-I Burial Ground ${ }^{27}$,

15 Vishnevskaia O. A. Kul'tura sakskikh plemen nizov'ev Syrdar'i v VII-V vv. do n. e. (po materialam Uigaraka). Moscow, 1973. Tabl. XVIII, 23.

${ }^{16}$ Erlikh V.R. Bronzovye uzdechnye nabory i problema khronologii predskifsogo i ranneskifskogo vremeni // Abramov A.P. Drevnosti Severnogo Kavkaza i Prichernomor'ia. Moscow, 1991. P.38-39; Leskov A.M., Erlikh V.R. Mogil'nik Fars/Klady. Pamiatnik perekhoda ot epokhi pozdnei bronzy k rannemu zheleznomu veku na Severo-Zapadnom Kavkaze. Moscow, 1999. P. 154; Erlikh V.R. Khronologicheskaia skhema predskifskikh drevnostei iuga Vostochnoi Evropy A.I.Terenozhkina i protomeotskaia gruppa pamiatnikov. Sovremennoe sostoianie problemy // Rannii zaliznii vik Evraziii: do 100-richchia vid narodzhennia Oleksiia Ivanovicha Terenozhkina/ Rannii zheleznyi vek Evrazii / ed. by S. A. Skoryi. Kiev, 2007. P. 154; Val'chak S. B.: 1) Khronologiia Chernogorovskogo etapa (po materialam uzdechnykh naborov) // Tezisy dokladov mezhdunarodnoi konferentsii "Problemy skifo-sarmatskoi arkheologii Severnogo Prichernomor'ia" posviashch. 95-letiiu so dnia rozhdeniia professora B. N. Grakova II / ed. by G. N. Toshchev. Zaporozhe, 1994. P.41-42; 2) Konskoe snariazhenie v pervoi treti I-go tys. do n. e. na iuge Vostochnoi Evropy. Moscow, 2009. P.94.

17 Valchak S. B.: 1) Predmety epokhi pozdnei bronzy - rannego zheleza iz kollektsii Vostochnoi Ukrainy i ikh analogii // Arkheologichnii litopis Livoberezhnoï Ukraïni / ed. by O.B.Suprunenko, V.S. Andrienko. Ch. 1-2. Poltava, 1998. Ill. 4, 3-4; 2) Konskoe snariazhenie v pervoi treti... Ill. 31, 4; Ill. 34, 9.

18 Val'chak S. B. Konskoe snariazhenie v pervoi treti.... Ill. 70, 1.

19 Ibid. Ill. $29,7$.

20 Ibid. Ill. 62, 2.

${ }^{21}$ Ibid. Ill. 76, 4.

${ }^{22}$ Erlikh V.R. Severo-Zapadnyi Kavkaz v nachale zheleznogo veka. Moscow, 2007. Pic. 62, 1.

23 Val'chak S. B. Konskoe snariazhenie v pervoi treti... Ill. 81, 1.

${ }^{24}$ Ibid. Ill. 99, 2.

25 Ibid. Ill. 80, 11.

26 Ibid. Ill. 32, 2.

${ }^{27}$ Erlikh V.R., Val'chak S. B., Maslov V.E. Issledovaniia kurgana 2 mogil'nika Uashkhitu I v Adygee // Arkheologicheskie otkrytiia 2005 goda. Moscow, 2007. P. 350. 
grave 136 of Starshee Akhmylovo ${ }^{28}$, at the Zalevki excavation site $^{29}$, the kurgan outside the Stepantsy village ${ }^{30}$ and the Gireeva mogila ${ }^{31}$. The most Western artifact was found in Moldavia $^{32}$.

Similar relief-ornamented bits come from kurgan 1 of Uashitu-I Burial Ground with side pieces that are rod-shaped with tubular structured holes, hem-stitched with Maltese cross-shaped buckles ornamented with a sun motif ${ }^{33}$. The artifacts from this complex are of importance among the Novocherkassk-type artifacts as the elements of wagon burial can be found in the kurgan. Also, the tubular structured, three-holed, so-called "Uashitu-Zhabotin" type side-pieces can be found among the horse tack collection. On the basis of the remnants of the laminae of the armor and the bronze cauldron made of nailed bronze sheets, the material excavated from the kurgan can be dated to between the end of the $8^{\text {th }}-$ the beginning of the $7^{\text {th }}$ century $\mathrm{BC}^{34}$. Similary relief-ornamented bits, which were made with emphatic supplementary holes on the stirrup-shaped ending, were found in kurgan 1 of the Khadzhokh Burial Ground ${ }^{35}$.

Based on the assessment of the double-ringed relief-ornamented bits mentioned above and the opinion of V.R. Erlikh and S. B. Val'chak, it can be determined that at the end of the $8^{\text {th }}$ - the beginning of the $7^{\text {th }}$ century BC characteristics of horse tacks were signinficantly changing. Along with these changes, the classic Novocherkassk-type bits had become more uniform. According to S. B. Val'chak, the lengthening of the mouthpiece of the bit may indicate that a different type of horse was used. However, this opinion cannot be proven yet due to the lack of horse skeletons. At the same time, it's possible to allude to the Zhabotin-type horse tack, the relief-ornamented bit of which discovered in kurgan 524 near the titular village of Zhabotin may be emphasized ${ }^{36}$. The mentioned type of tack is primarily common in the regions where the classic Novocherkassk-type tack is present as well, that is, in the headlands of the North-Western Caucasus and along the river Dnieper ${ }^{37}$.

According to S. B. Val'chak, in most cases the rectangular relief patterns only on one side of the mouth-piece of the bit served to increase the effect of the bit which would exert greater physical pressure on the horse's tongue and the space between the jaw-teeth. This made it easier for the horseman to control the horse by hand ${ }^{38}$.

In this regard, it is worth mentioning the morphological characteristics of the bits with "pawn-shaped" external ring excavated from the burial mounds of Tuva. Among them there was the bronze bit from grave 1 of kurgans 1-2 of the Khemchik-Bom III Burial Ground, one component of which is covered in the relief patterns similar to the Ar-

28 Val'chak S. B. Konskoe snariazhenie v pervoi treti... Ill. 103, 7.

29 Ibid. Ill. 87, 9.

${ }^{30}$ Ibid. Ill. 89, 4.

31 Ibid. Ill. 86, 1-2.

32 Ibid. Ill. 89, 7.

${ }^{33}$ Erlikh V.R.: U istokov ranneskifskogo kompleksa. Moscow, 1994. P. 25-27, tabl. 5, 1, 2, 4; tabl. 5, 5, 6, 8; Khronologicheskaia skhema... Ill. 80, 11.

34 Erlikh V.R. U istokov... P. 34-36.

35 Val'chak S. B. Konskoe snariazhenie v pervoi treti... Ill. 65, 1.

36 Val'chak S.B.: 1) Udila predskifsogo perioda i kimmeriiskie loshadi Vostochnoi Evropy // Khar'kovskii istoriko-arkheologicheskii ezhegodnik «Drevnosti» / ed. by S. I. Posokhov. Khar'kov, 1995. P. 44-47; 2) Konskoe snariazhenie v pervoi treti... P. 48-50.

37 Erlikh V.R.: 1) Severo-Zapadnyi Kavkaz... P.117; 2) Khronologicheskaia skhema... P. 156; Val'chak S. B. Konskoe snariazhenie v pervoi treti... P. 93-94.

38 Valchak S. B. Konskoe snariazhenie v pervoi treti... P. 41. 
zhan bits and the Eastern European bits, whilst the other component has the rectangular reliefs on the part close to the external ring of the mouthpiece ${ }^{39}$. Such relief ornamentation is present in the so-called ritual treasure trove of the above mentioned kurgan in the Khemchik-Bom Burial Ground ${ }^{40}$, as well as in the kurgans of the Uigarak cemeteries from east of Lake Aral, where the reliefs also ornament only one side of the mouthpiece, the part closer to the external ending, but in a significantly more emphatic manner ${ }^{41}$.

The closer analogies of the bit with the external stirrup-shaped end are connected to the bits with supplementary holes, which can be found sporadically in the Minusinsk Basin dated by P. I. Shul'ga to $8-7^{\text {th }}$ century $\mathrm{BC}^{42}$ and collections of horse tack and artifact materials from the (end of) $7^{\text {th }}$ century $\mathrm{BC}^{43}$ from the Altai region, but they are also present in smaller numbers in the collections of horse tacks of the Eastern European classic Novocherkassk and the pre-early-Scythian period (see above).

It is worth noting that besides the bits we have studied, another type of bit, also from the central burial chamber, is known, which has an additional outside circular fastener, and a thick mouthpiece, which is twisted ${ }^{44}$. P. I. Shul'ga believed that the earliest varieties of the bit with the supplementary holes found in the central chamber ${ }^{45}$ are the types of bits proliferated through North Eastern China ${ }^{46}$ and the Altai ${ }^{47}$ from the $7^{\text {th }}$ century BC. While studying the bits of Arzhan-1 kurgan, K. V. Chugunov confirmed P. I. Shulga's views $^{48}$. P. I. Shul'ga clarified N. A. Bokovenko's theory about the evolution of the bronze bits of the Minusinsk Basin. In their dissertation of 1986, N. A. Bokovenko assessed the phases of development of the bronze bits of Inner Asia, during which an intermediary type between the bits with supplementary holes and the bits with stirrup-form endings could be distinguished ${ }^{49}$. On the other hand, P. I. Shulga came to the conclusion that no such intermediary type existed, but both types were developed at the same time, independently of the each other ${ }^{50}$.

39 Grach A.D. Drevnie kochevniki v tsentre Azii. Moscow, 1980. P. 127, ill. 109, 1; Bokovenko N.A. Odin iz variantov konskoi uzdy skifskoi epokhi v Tsentral'noi Azii // Snariazhenie verkhovogo konia na Altae v rannem zheleznom veke i srednevekov'e / ed. by Iu. F. Kiriushin, A. A. Tishkin. Barnaul, 1998. Ill. 5, 1.

40 Bokovenko N. A. Odin iz variantov konskoi uzdy skifskoi epokhi v Tsentral'noi Azii // Snariazhenie verkhovogo konia... Ill. 6, 1 .

${ }^{41}$ Vishnevskaia O.A. Kul'tura sakskikh plemen nizov'ev Syrdar'i v VII-V vv. do n.e. (po materialam Uigaraka). Tabl. I, 12; tabl. III, 13; tabl. XI, 12.

42 Shul'ga P.I. Konskoe snariazhenie rannikh kochevnikov Minusinskoi kotloviny (po materialam Minusinskogo muzeia im. N. M. Mart'ianova). Novosibirsk, 2013. Ill. 21, 1, 22, 5.

43 Type 2 by the tipology of P. I. Shul'ga: Shul'ga P. I. Snariazhenie verkhovoi loshadi i voinskie poiasa na Altae. Chast' I. Ranneskifskoe vremia. Barnaul, 2008. Ill. 56, 5-6.

${ }^{44}$ Gryaznov M.P. Arzhan. Foto i chertezhiki raskopok 1971-1972 gg. // Nauchnyi arkhiv IA RAN R-1. №4833a/109. 1973.

${ }^{45}$ Shul'ga P.I. Snariazhenie verkhovoi loshadi i voinskie poiasa na Altae. Chast' I. Ranneskifskoe vremia. P.73.

46 Shul'ga P. I. Sin’tszian v VIII-III vv. do n.e. (Pogrebal'nye kompleksy. Khronologiia i periodizatsiia). Barnaul, 2010. Ill. 13, 14.

47 Shul'ga P. I. Mogil'nik ranneskifskogo vremeni Gilevo-10 v predgor'iakh Altaia. Novosibirsk, 2016. Pic. 34,1 .

48 Chugunov K. V. Arzhan-1 i Arzhan-2: sravnitel'nyi analiz // Nasledie narodov Tsentral'noi Azii i sopredel'nykh territorii: izuchenie, sokhranenie i ispol'zovanie. Materialy konferentsii $\mathrm{v} 2$-kh chastiakh. Chast' 1 / ed. by U. B. Nurzat. Kyzyl, 2009. P. 48-52.

49 Bokovenko N.A. Nachal'nyi etap kul'tury rannikh kochevnikov Saiano-Altaia (po materialam konskogo snariazheniia). Diss. ... kand. ist nauk. Leningrad, 1986. P. 91.

50 Shul'ga P. I. Konskoe snariazhenie rannikh kochevnikov... P. 21-22. 
The specifically structured bronze bits from Tuva and the Altai region with stirrup-shaped, so-called "pawn shaped" endings can be connected with the Arzhan bit. However, the mouthpieces of these bits are not ornamented, and they are largely found next to Y-shaped bronze side pieces ${ }^{51}$. In the course of his research, A. A. Tishkin examined the structures of the bit and of the side piece, and came to the conclusion that the form of the outside ring is very special, and matches exactly the side piece. In his opinion, this structure seems to have been an imitation of a bit with a rigid structure ${ }^{52}$. These types of side pieces were widespread in the same areas as the bronze bits ending in a "pawn" shape, or, in other words, primarily in the Altaj foothills, high-altitude rural areas ad in the Ulug-Khorum microregion (Tuva) ${ }^{53}$.

V. B. Borodaev has limited the use of this type of horse tack to a period of half a century in the $7^{\text {th }}$ century $\mathrm{BC}^{54}$. According to $\mathrm{K}$. V. Chugunov, the Y-shaped cheek-pieces must have been a local characteristic, and the T-shaped hook on the middle of the side piece from the collection found in grave 33 of Uigarak served to replace the central hole of the side-piece ${ }^{55}$. Based on the arrowheads of the Sakar Chaga 23 Burial Ground, the kurgan can be dated back to the end of the $8^{\text {th }}$ century BC-beginning of the $7^{\text {th }}$ century $\mathrm{BC}^{56}$. In the course of studying the Altai horse tack, P.I.Shulga thought that the development of the Y-shaped side pieces might have already been finished by the turn of the $8^{\text {th }} / 7^{\text {th }}$ century BC in Kazakhstan, in the areas of Altai and Tuva ${ }^{57}$. Additionally, he cites an article by K. A. Akishev and A. K. Akishev, in which the two researchers considered the Y-shaped side piece and the rigid structure bit to have emerged approximately at the same time ${ }^{58}$.

${ }^{51}$ N. A. Bokovenko's D7 type: Bokovenko N.A. Nachal'nyi etap... P.91; Kiriushin-Tishkin type III: Kiriushin Iu.F., Tishkin A. A. Skifskaia epokha gornogo Altaia I. Kul'tura naselenie v ranneskifsoe vremia. Barnaul, 1997. P. 69; P. I. Shul'ga's type 6, Group 2. varieties 1-2: Shul'ga P. I. Snariazhenie verkhovoi loshadi... P.70-71.

52 Tishkin A. A. Nakhodki nekotorykh elementov konskogo snariazheniia skifskoi epokhi v predgornoi zone Altaia // Snariazhenie verkhovogo konia na Altae v rannem zheleznom veke i Srednevekov'e / eds Iu. F. Kiriushin, A. A. Tishkin. Barnaul, 1998. P.79-87, Ill. 3, 1, 4; Shul'ga P. I.: 1) Ranneskifskaia upriazh' VII - nach. VI vv. do n. e. po materialam pogrebeniia na r. Charysh // Snariazhenie verkhovogo konia.... P. 33; ill. 10, 3, 17-19; 2) Snariazhenie verkhovoi loshadi... P. 60-61.

${ }^{53}$ Marsadodov L.S. Osnovnye tendentsii v izmenenii form udil, psaliev i priazhek konia na Altae v VIII-V vekakh do n. e. // Snariazhenie verkhovogo konia na Altae v rannem zheleznom veke i Srednevekov'e / eds Iu. F. Kiriushin, A. A. Tishkin. Barnaul, 1998. P. 6; Shul'ga P. I. Snariazhenie verkhovoi loshadi i voinskie poiasa na Altae. Chast' I. Ranneskifskoe vremia. P. 67, 74.

54 Borodaev V.B. Vakulikhinskii klad (Kompleks nakhodok ranneskifskogo vremeni s mestonakhozhdeniia Vakulikha-1) // Snariazhenie verkhovogo konia. na Altae v rannem zheleznom veke i Srednevekov’e / eds Iu. F. Kiriushin, A. A. Tishkin. Barnaul, 1998. P.73.

55 Chugunov K. V. Uzdechnye komplekty Aldy-Bel'skoi kul'tury v kontekste razvitiia konskogo snariazheniia // Snariazhenie kochevnikov Evrazii: sbornik nauchnykh trudov / ed. by A. A. Tishkin. Barnaul, 2005. P. $103-108$.

56 Iablonskii L. T. Khronologiia drevneishikh pamiatnikov rannego zheleznogo veka Srednei Azii i Kazakhstana (po materialam Priaral'ia) // Sarmatskie kul'tury Evrazii: problemy regional'noi khronologii / ed. by A. D. Tairov. Krasnodar, 2004. P. 51.

57 Shul'ga P. I. Snariazhenie verkhovoi loshadi... P. 67, 75-76, see: Tishkin A. A. Nakhodki nekotorykh elementov konskogo snariazheniia... P.90.

58 Akishev K.A., Akishev A.K. Problema khronologii rannego etapa sakskoi kul'tury // Arkheologicheskie pamiatniki Kazakhstana. Alma-Ata, 1978. P. 46, 59. 


\section{Composition of metal of the bronze objects of Arzhan-1 mound and the Early Scythian Age of Central Asia}

In 1975, B. N. Pjaktin and D. V. Naumov carried out spectral analytical examinations of the bronze objects in the central chamber, however, they did not take each object into account. During the examinations, it was determined that the bit with the "pawn" shaped ending was made of arsenical bronze ( $\mathrm{Sn}-0,27 \%, \mathrm{~Pb}-1,6 \%, \mathrm{Zn}-0,01 \%, \mathrm{Bi}-0,03 \%$, $\mathrm{Sb}-0,18 \%$, As - 1,7\%, Ni - 1,0\%, $\mathrm{Co}-0,01 \%, \mathrm{Fe}-0,4 \%)$, whilst the part ending in the external ring has a higher tin content $(\mathrm{Sn}-6,0 \%, \mathrm{~Pb}-0,05 \%, \mathrm{Zn}-0,1 \%)^{59}$.

Moreover, besides the bits we have studied, there is another type of bit, also from the central burial chamber, which has an additional outside circular fastener and a thick mouthpiece, which is twisted ${ }^{60}$. The metallurgical test showed that this bit contains tin and arsenic as well, and also smaller amounts of trace of metal contamination ( $\mathrm{Sn}-4,5 \%$, $\mathrm{Pb}-0,1 \%, \mathrm{Sb}-0,17 \%$, As $-1,6 \%, \mathrm{Fe}-2,0 \%)^{61}$.

The spectrum analysis of 1975 were carried out on the bits from the eastern sector of the central chamber, on the one hand, and on the two bronze blades and bronze picks found in the western sector. on the other hand The tin content of the two blades is clear, however their ratios are different (the blade, No.323: $\mathrm{Sn}-12,0 \%, \mathrm{~Pb}-0,03 \%, \mathrm{Sb}-$ 0,7 \%; blade, No. 324: $\mathrm{Sn}-15 \%, \mathrm{~Pb}-0,1 \%, \mathrm{Bi}-0,1 \%$, Sb - 0,3\%, Ni - 0,25\%) ${ }^{62}$. As a result of the analysis, B. N. Pjatkin determined that the objects may have been made independently of each other, and in different workshops ${ }^{63}$. In contrast with the bronze objects of the central chamber, all of the bits and side-pieces from the $2^{\text {nd }}$ until the $37^{\text {th }}$ burial chamber are made of arsenic bronze / copper bronze ${ }^{64}$.

According to the early Iron Age metal research of Inner Asia, it is an accepted fact that arsenic bronze was more commonly used in the late Iron Age Minusinsk Hollow, in the late Bronze Age and during the Podgornovo phase, while tin bronze was used more rarely. This situation changed during the time of the Aldy-Bel' culture, when tin bronze began to be used widely ${ }^{65}$.

Nevertheless, the metal composition of the bronze objects of the Arzhan-1 complex differs from the typical metal objects of the early Tagar culture. Taking into account the previously drawn conclusions about these types of bits as well as the results of 1975 spec-

59 Pyatkin B. N. Rezul'taty spektral'nogo analiza bronz kurgana Arzhan // Drevnie gorniaki i metallurgi Sibiri / ed. by Iu. F. Kiriushin. Barnaul, 1983. p. 86, table, analyses N 327 and 328.

${ }^{60}$ Gryaznov M.P. Arzhan. Foto i chertezhiki raskopok 1971-1972 gg. // Nauchnyi arkhiv IA RAN R-1. N 4833a/109. 1973.

${ }^{61}$ Pyatkin B. N. Rezul’taty spektral’nogo analiza bronz kurgana Arzhan. Table, analysis № 326.

62 Ibid. P. 86, table, analysis N 323-324.

${ }^{63}$ Ibid. P. 87.

${ }^{64}$ See: Ibid. Table, pp. 89-94.

${ }^{65}$ Khavrin S. V.: 1) Metallicheskie izdeliia epokhi pozdnei bronzy - rannego zheleza iz Askizskogo raiona Khakasii // Aleksandrov S. V., Paul's E. D., Podol'skii M.L. Drevnosti Askizskogo raiona Khakasii. St. Petersburg, 2001. P.93-94; 2) Metall skifskikh pamiatnikov i kurgana Arzhan // Stepi Evrazii v drevnosti i Srednevekov'e. Materialy mezhdunarodnoi nauchnoi konferentsii, posviashchennoy 100-letiiu so dnia rozhdeniia M. P. Gryaznova. Book 2 / ed. by Iu. Iu. Piotrovskii. St. Petersburg, 2003. P.171-173; 3) Spektral'nyi analiz bronzovykh izdelii skifskogo vremeni Saiano-Altaia i problemy khronologii tagarskoi kul'tury // Arkheologiia Iuzhnoi Sibiri: idei, metody, otkrytiia: sbornik dokladov mezhdunarodnoy nauchnoi konferentsii, posviashchennoi 100-letiu so dnya rozhdeniya chlena-korrespondenta Rossiiskoy akademii nauk Sergeia Vladimirovicha Kiseleva, g. Minusinsk, 20-26 iunia 2005 g. / ed. by G. G. Korol. Krasnoiarsk, 2005. P. 96-98. 
trum analysis carried out by B. N. Pjatkin and C. V. Khavrin during their research in connection with the early Tagar metal objects, the metal composition of the weapons and horse tack found in the central chamber surely indicates that these were made independently of one another in separate workshops. In addition, the diversity of the objects in the central chamber indicates that the use of the tin bronze may have already been taking off throughout the region during the construction of the Arzhan complex was built. At the same time, the bronze horse tacks farther from the central chamber help to confirm the hypothesis that arsenic bronze casting hadn't soon gone out of fashion, but instead remained in use.

\section{Summary}

Consequently, we can conclude that on the basis of the types of horse bits found in the eastern corner of the central chamber of the Arzhan-1 kurgan, which we have analyzed, as well as their conditions and all data collected in connection with these objects, it is possible to view the history of the development of horse equipment from a new angle.

The bit that we have analyzed consists of two separate parts. One of the parts, ending in a circle, was cast with a double-sided mold. The other piece has one side indented with two rows of square reliefs. The process of the manufacturing of the bit may be recreated in the following way: 1) the symmetrical component of the bit is molded using a double-sided mold; 2) the mouthpiece of the symmetrical component of the bit is welded to the external stirrup ending; 3 ) the asymmetrical component ending in a ring is molded;4) the internal ring is made from an open ring and connected to the mouthpiece; 5) the internal ring is attached to the mouthpiece of the symmetrical component of the bit.

The result of a comparative assessment of the horse tack discovered in the central burial chamber determines that the closest parallels of the relief-ornamented component of the bit as regards the two or more rows of rectangular reliefs, can be found in the collections of Novocherkassk and early Zhabotin types of horse tacks, and they also occur sporadically in the kurgans of burial grounds east of Lake Aral and at the Tuva site. The external ring of the relief-ornamented component cannot be considered a typological characteristic in terms of its form, which is, in fact, a molding error, possibly the result of re-use. Based on the external ending of the bit-component, it resembles more the bits fashioned with supplementary holes and ending in a trapezoid stirrup form, which can be exemplified by well-known objects from the Minusinsk Basin and the Altai regions.

According to the results of the metallurgical analyses, the diversity of the objects in the central chamber indicates that the use of the tin bronze may have already been taking off throughout the region during the construction of the Arzhan complex. At the same time, the bronze horse tacks farther from the central chamber help to confirm the hypothesis that the technique of arsenic bronze casting hadn't not soon gone out of fashion, but instead was still in use. However, only a new comprehensive re-examination of the metal objects found in the kurgan burial chambers could enable to draw more specific conclusions.

Furthermore, quite interesting relationships can be observed between the features of the types of objects known to date, their respective locations in the kurgan burial system, and the order in which the kurgan was built. M.P. Griaznov's excavation report attempts to reconstruct the phases of the construction of the kurga, when the central chamber was 
built first, with its palatial burial grounds, as well as the places of escorts. Following this, the construction proceeded radially outward, toward the East and Southeast, and then outward, while the outer chambers were built ${ }^{66}$. Griaznov's architectural reconstruction and a comparison of the features of the finds from the burial chambers support the theory, according to which at the start of the Scythian Age in Tuva, arsenic and tin bronze were used concurrently.

Consequently, we can say that by the start of the Arzhan time period, the system of cultural and metallurgical relationship characterised the Aldy-Bel' culture in the early Scythian Age ${ }^{67}$ was already starting to be formed.

Taking into account all of the features and conditions of the bits from the central chamber of Arzhan-1 kurgan, it is impossible to identify them at an earlier time than the middle/second half of the $8^{\text {th }}$ century BC. According to radiocarbon analyzes, research the kurgan should be dated to the very end of the $9^{\text {th }}$ century BC-beginning of the $8^{\text {th }}$ century $\mathrm{BC}^{68}$, however, in view of the new considerations the results that were previously regarded as certain have to be revised. During the examination of the Arzhan-1 complex, P. I. Shulga indicated a few components of horse tack and types of bits, among which were those discovered in the central chamber (the bits we are examining in the article), whose characteristics can be dated to a later period compared to the results of the C14 examinations, to the $7^{\text {th }}-6^{\text {th }}$ century $B C^{69}$. Therefore, the question arises whether these relief-ornamented and curlicue-shafted, supplementary holed bits may have been buried, due to their later characteristics, not when the mound was originally built and the horses along with their tacks where interred, but were placed in the eastern sector of the central chamber during later burials at the site. This hypothesis is, however, difficult to prove for several reasons. Firstly, the fact that the chamber had been continually disturbed was obvious from the beginning. Furthermore, due to the incomplete nature of the reports made during the excavations $\mathrm{s}^{70}$, the processes of the excavation of the eastern sector of the central chamber are difficult or impossible to reconstruct.

The examination of some of the horse tack of the Arzhan-1 kurgan raises numerous questions, which calls for a comprehensive re-examination of all aspects of the finds, which will assist with the research into understanding the evolution and development of early Scythian cultures of Inner Asia, as well as give a deeper understanding of their relations with neighboring regions.

66 Gryaznov M.P. Otchet o raskopkakh kurgana Arzhan v 1973-1974 gg. P. 10.

${ }^{67}$ Chugunov K. V.: 1) Absoliutnaia khronologiia tagarskoi kul'tury — vzgliad izvne // Arkheologiia Iuzhnoi Sibiri: idei... P. 103; 2) Perekhod ot epokhi bronzy k epokhe rannego zheleza na territorii SaianoAltaia (prezentatsiia kontseptsii) // Trudy IV (XX) Vserossiiskogo arkheologichesktogo s"ezda v Kazani. 2014. Vol. 1. P. 679-680.

${ }^{68}$ Evraziia v skifskuiu epokhu. Radiouglerodnaia i arkheologicheskaia khronologiia. St. Petersburg, 2005. P. 67-102; Zaitseva G., Chugunov K. V., Alekseev A. Iu., Dergachev V.A., Vasilev S. S., Sementsov A. A., Kuk G. T., Skott E.M., Van der Plikht Kh., Bokovenko N.A., Kul'kova M.A., Burova N.D., Lebedeva L.M., Iunger Kh., Sonninen E. Istoriia i rezul'taty radiouglerodnogo datirovaniia kurgana Arzhan // Radiouglerod $\mathrm{v}$ arkheologicheskikh i paleoekologicheskikh issledovaniiakh. (Materialy konferentsii, posviashchennoi 50-letiiu radiouglerodnoi laboratorii IIMK RAN, 9-12 aprelia 2007 g.) / eds G. I.Zaitseva, M. A. Kul'kova. St. Petersburg, 2007. P. 646.

69 Shul'ga P.I. K otnositel'noi khronologii kurgana Arzhan-1// Problemy arkheologii, etnografii, antropologii Sibiri i sopredelnykh territorii. 2005. Vol. XI, Part 1. P. 495-496.

70 Gryaznov M.P. Otchet o raskopkakh kurgana Arzhan v 1971-1972 gg. P. 13-19. 


\section{References}

Akishev K. A., Akishev A.K. Problema khronologii rannego etapa sakskoi kul'tury. Arkheologicheskie pamiatniki Kazakhstana. Alma-Ata, Nauka KazSSR Publ., 1978, pp.38-63. (In Russian)

Bokovenko N. A. Nachal'nyi etap kul'tury rannikh kochevnikov Saiano-Altaia (po materialam konskogo snariazheniia). Diss. ... kand. ist nauk. Leningrad, 1986, 240 p. (In Russian)

Bokovenko N. A. Problemy genezisa pogrebal'nogo obriada rannekochevnicheskoi znati Tsentral'noi Azii. Elitnie kurgany stepei Evrazii v skifo-sarmatskuiu epokhu. Ed. by A. Iu. Alekseev. St. Petersburg, Fond fundamental'nikh issledovaniy RAN Publ., 1994, pp.41-48. (In Russian)

Bokovenko N.A. Odin iz variantov konskoi uzdy skifskoi epokhi v Tsentral'noi Azii. Snariazhenie verkhovogo konia na Altae v rannem zheleznom veke i srednevekov'e. Eds Iu. F. Kiriushin, A. A. Tishkin. Barnaul, Altai State University Press, 1998, pp. 50-55. (In Russian)

Bokovenko N. A. The Origin of Horse Riding and the Development of Central Asian Nomadic Riding Harnesses. J. D. Kimball. Kurgans, Ritual Sites and Settlements Eurasian Bronze and Iron Age. BAR International Series 890. Oxford, Archeopress Publ., 2000, pp. 304-310.

Borodaev V.B. Vakulikhinskii klad (Kompleks nakhodok ranneskifskogo vremeni s mestonakhozhdeniia Vakulikha-1). Snariazhenie verkhovogo konia na Altae v rannem zheleznom veke i Srednevekov'e. Eds Iu. F. Kiriushin, A. A. Tishkin. Barnaul, Altai State University Press, 1998, pp. 56-73. (In Russian)

Chlenova N. L. Eshche raz o date olennogo kamnia iz Arzhana. Kratkie soobshcheniia Instituta arkheologii, 1993, iss. 204, pp. 24-29. (In Russian)

Chlenova N. L. Tsentral'naia Aziia i skify I. Data kurgana Arzhan i ego mesto v sisteme kul'tur skifsogo mira. Moscow, IA RAN Publ., 1997, 98 p. (In Russian)

Chugunov K. V. Absoliutnaia khronologiia tagarskoi kul'tury - vzgliad izvne. Arkheologiia Iuzhnoi Sibiri: idei, metody, otkrytiia: sbornik dokladov mezhdunarodnoy nauchnoi konferentsii, posviashchennoi 100-letiu so dnya rozhdeniya chlena-korrespondenta Rossiiskoy akademii nauk Sergeia Vladimirovicha Kiseleva, g. Minusinsk, 20-26 iunia 2005 g. Ed. by G. G. Korol'. Krasnoiarsk, V. P. Astaf'ev Krasnoiarsk State Pedagogical University Press, 2005, pp. 102-104. (In Russian)

Chugunov K. V. Arzhan-1 i Arzhan-2: sravnitel'nyi analiz. Nasledie narodov Tsentral'noi Azii i sopredel'nykh territorii: izuchenie, sokhranenie i ispol'zovanie. Materialy konferentsii v 2-kh chastiakh. Chast' 1 . Ed. by U. B. Nurzat. Kyzyl, KTsO Anyiak Publ., 2009, pp. 48-52. (In Russian)

Chugunov K. V. Perekhod ot epokhi bronzy k epokhe rannego zheleza na territorii Saiano-Altaia (prezentatsiia kontseptsii). Trudy IV (XX) Vserossiiskogo arkheologichesktogo s"ezda v Kazani, 2014, vol. 1., pp. 679-683. (In Russian)

Chugunov K. V. Uzdechnye komplekty Aldy-Bel'skoi kul'tury v kontekste razvitiia konskogo snariazheniia. Snariazhenie kochevnikov Evrazii: sbornik nauchnykh trudov. Ed. by A. A. Tishkin. Barnaul, Altai State University Press, 2005, pp. 103-108. (In Russian)

Erlikh V.R. Bronzovye uzdechnye nabory i problema khronologii predskifsogo i ranneskifskogo vremeni. Abramov A. P. Drevnosti Severnogo Kavkaza i Prichernomor'ia. Moscow, Nauka Publ., 1991, pp. 35-39. (In Russian)

Erlikh V.R. Khronologicheskaia skhema predskifskikh drevnostei iuga Vostochnoi Evropy A. I. Terenozhkina i protomeotskaia gruppa pamiatnikov. Sovremennoe sostoianie problemy. Rannii zaliznii vik $\epsilon v$ razii: do 100-richchia vid narodzhennia Oleksiia Ivanovicha Terenozhkina / Rannii zheleznyi vek Evrazii. Ed. by S. A. Skoryi. Kiev, TOV VPD Format Publ., 2007, pp. 152-157. (In Russian)

Erlikh V.R. Severo-Zapadnyi Kavkaz v nachale zheleznogo veka. Moscow, Nauka Publ., 2007, 430 p. (In Russian)

Erlikh V.R. U istokov ranneskifskogo kompleksa. Moscow, Izdatel'stvo "Gosudarstvennogo Muzeia Vostoka" Publ., 1994, 148 p. (In Russian)

Erlikh V.R., Val'chak S. B., Maslov V.E. Issledovaniia kurgana 2 mogil'nika Uashkhitu Iv Adygee. Arkheologicheskie otkrytiia 2005 goda. Moscow, Nauka Publ., 2007, pp.350-354. (In Russian)

Evraziia v skifskuiu epokhu. Radiouglerodnaia i arkheologicheskaia khronologiia. St. Petersburg, Teza Publ., 2005, 290 p. (In Russian)

Grach A. D. Drevnie kochevniki v tsentre Azii. Moscow, Nauka Publ., 1980, 256 p. (In Russian)

Gryaznov M. P. Arzhan - "tsarskii" kurgan ranneskifskogo vremeni. Leningrad, Nauka Publ., 1980, 62 p. (In Russian)

Gryaznov M.P. Arzhan. Foto i chertezhi raskopok 1973 g. Nauchno-otraslevoy arkhiv Instituta Arkheologii Rossiiskoi Akademii Nauk, R-1, no. 5579a, 1974. (In Russian)

Gryaznov M. P. Arzhan. Foto i chertezhiki raskopok 1971-1972 gg. Nauchno-otraslevoy arkhiv Instituta Arkheologii Rossiiskoi Akademii Nauk, R-1, no. 4833a, 1973. (In Russian) 
Gryaznov M.P. Der Großkurgan von Aržan in Tuva, Südsibirien. München, Verlag C. H. Beck Publ., 1984, 90 S. (In German)

Gryaznov M.P. K voprosu o slozhenii kul'tur skifo-sibirskogo tipa v sviazi s otkrytiem kurgana Arzhan. Kratkie soobshcheniia Instituta arkheologii, 1978, no. 154, pp.9-18. (In Russian)

Gryaznov M.P. Nachal'naia faza razvitiia skifo-sibirskikh kul'tur. Arkheologiia Iuzhnoi Sibiri, 1983, iss. 12, pp. 3-18. (In Russian)

Gryaznov M. P. Otchet o raskopkakh kurgana Arzhan v 1971-1972 gg. Nauchno-otraslevoy arkhiv Instituta Arkheologii Rossiiskoi Akademii Nauk, R-1, no. 4833, 1973. (In Russian)

Gryaznov M. P. Otchet o raskopkakh kurgana Arzhan v 1973-1974 gg. Nauchno-otraslevoy arkhiv Instituta Arkheologii Rossiiskoi Akademii Nauk, R-1, no. 5579, 1975. (In Russian)

Gryaznov M.P., Mannai-ool M. Kh. Kurgan Arzhan - mogila "tsaria" ranneskifskogo vremeni. Uchenye zapiski UZTNIIIaLI, 1973, iss. XVI, pp. 191-206. (In Russian)

Iablonskii L. T. Khronologiia drevneishikh pamiatnikov rannego zheleznogo veka Srednei Azii i Kazakhstana (po materialam Priaral'ia). Sarmatskie kul'tury Evrazii: problemy regional'noi khronologii. Ed. by A. D. Tairov. Krasnodar, Firma NSS Publ., 2004, pp. 45-68. (In Russian)

Khavrin S. V. Metallicheskie izdeliia epokhi pozdnei bronzy — rannego zheleza iz Askizskogo raiona Khakasii. Aleksandrov S. V., Paul's E. D., Podol'skii M. L. Drevnosti Askizskogo raiona Khakasii. St. Petersburg, Feniks Publ., 2001, pp. 94-97. (In Russian)

Khavrin S. V. Metall skifskikh pamiatnikov i kurgana Arzhan. Stepi Evrazii v drevnosti i Srednevekov'e. Materialy mezhdunarodnoi nauchnoi konferentsii, posviashchennoy 100-letiiu so dnia rozhdeniia M. P. Griaznova. Book 2. Ed. by Iu. Iu. Piotrovskii. St. Petersburg, IIMK RAN Publ., 2003, pp. 171-173. (In Russian)

Khavrin S. V. Spektral'nyi analiz bronzovykh izdelii skifskogo vremeni Saiano-Altaia i problemy khronologii tagarskoi kul'tury. Arkheologiia Iuzhnoi Sibiri: ideia, metody, otkrytiia: sbornik dokladov mezhdunarodnoy nauchnoi konferentsii, posviashchennoi 100-letiu so dnya rozhdeniya chlena-korrespondenta Rossiiskoy akademii nauk Sergeia Vladimirovicha Kiseleva, g. Minusinsk, 20-26 iunia 2005 g. Ed. by G. G. Korol'. Krasnoiarsk, V. P. Astaf'ev Krasnoiarsk State Pedagogical University Press, 2005, pp. 96-98. (In Russian)

Kiriushin Iu. F., Tishkin A. A. Skifskaia epokha gornogo Altaia I. Kul'tura naselenie v ranneskifsoe vremia. Barnaul, Altai State University Press, 1997, 234 p. (In Russian)

Kyzlasov L. R. Drevniaia Tuva (ot paleolita do IX v.). Moscow, Moscow State University Press, 1979, 208 p. (In Russian)

Leskov A. M., Erlikh V.R. Mogil’nik Fars/Klady. Pamiatnik perekhoda ot epokhi pozdnei bronzy k rannemu zheleznomu veku na Severo-Zapadnom Kavkaze. Moscow, Izdatel'stvo Gosudarstvennogo Muzeia Vostoka Publ., 1999, 162 p. (In Russian)

Marsadodov L.S. Osnovnye tendentsii v izmenenii form udil, psaliev i priazhek konia na Altae v VIII-V vekakh do n.e. Snariazhenie verkhovogo konia na Altae v rannem zheleznom veke i Srednevekov'e. Eds Iu. F. Kiriushin, A. A. Tishkin. Barnaul, Altai State University Press, 1998, pp. 5-24. (In Russian)

Marsadolov L. S. Tkani iz kurgana Arzhan v Tsentre Azii. Piatie istoricheskie chteniia pamiati M. P. Griaznova. Tezisy dokladov Vserossiiskoi nauchnoi koferentsii (Omsk, 19-20 okt. 2000 g.). Omsk, Omsk State University Press, 2000, pp. 72-75. (In Russian)

Marsadolov L.S. Rekonstruktsiia olennogo kamnia iz kurgana Arzhan-1. Vremia i kul'tura $v$ arkheologo-etnograficheskikh issledovaniiakh drevnikh i sovremennykh obshchestv Zapadnoi Sibiri i sopredelnykh territorii: problemy interpretatsii i rekonstruktsii. Materialy XIV Zapadno-Sibirskoi arkheologoetnograficheskoi konferentsii. Tomsk, Argaf-Press Publ., 2008. pp.60-64. (In Russian)

Minasian R.S. Metalloobrabotka $v$ drevnosti i Srednevekov'e. St.Petersburg, Izdatel'stvo Gosudarstvennogo Ermitazha Publ., 2014, 472 p. (In Russian)

Minasian R. S. Sposoby lit'ia bronzovykh udil v predskifskoe i skifskoe vremia. Elitnie kurgany stepei Evrazii $v$ skifo-sarmatskuiu epokhu (materialy zasedaniia "kruglogo stolia" 22-24. dekabria 1994. g. Sankt-Peterburg. St. Petersburg, Fond Fundamental'nikh issledovanii RAN, 1994, pp.157-163. (In Russian)

Pyatkin B. N. Rezul'taty spektral'nogo analiza bronz kurgana Arzhan. Drevnie gorniaki i metallurgi Sibiri. Ed. by Iu. F. Kiriushin. Barnaul, Altai State University Press, 1983, pp. 84-96. (In Russian)

Savinov D.G. Rekonstruktsiia pogrebal'nogo kompleksa kurgana Arzhan, ego komponenty i analogii. Severnaia Evraziia ot drevnosti do Srednevekov'ia. Tezisy konferentsii $k$ 90-letiiu so dnia rozhdeniia M. P. Griaznova. Ed. by B. P. Shilov. St.Petersburg, IIMK RAN Publ., 1992. pp. 108-114. (In Russian)

Savinov D. G. Rannie kochevniki Verkhnego Eniseia. Arkheologicheskie kul'tury i kul'turogenez. St.Petersburg, St. Petersburg State University Press, 2002, 204 p. (In Russian) 
Shul'ga P. I. K otnositel'noi khronologii kurgana Arzhan-1. Problemy arkheologii, etnografii, antropologii Sibiri i sopredelnykh territorii, 2005, vol. XI, part 1, pp.493-496. (In Russian)

Shul'ga P. I. Konskoe snariazhenie rannikh kochevnikov Minusinskoi kotloviny (po materialam Minusinskogo muzeia im. N. M. Mart'ianova). Novosibirsk, Institut arkheologii i etnografii SO RAN Publ., 2013, 148 p. (In Russian)

Shul'ga P. I. Mogil'nik ranneskifskogo vremeni Gilevo-10 v predgor'iakh Altaia. Novosibirsk, IPTs NGU Publ., 2016, 256 p. (In Russian)

Shul'ga P.I. Ranneskifskaia upriazh' VII - nach. VI vv. do n. e. po materialam pogrebeniia na r. Charysh. Snariazhenie verkhovogo konia na Altae v rannem zheleznom veke i srednevekov'e. Eds Iu. F. Kiriushin, A. A. Tishkin. Barnaul, Altai State University Press, 1998, pp. 25-29. (In Russian)

Shul'ga P. I. Sin'tszian v VIII-III vv. do n.e. (Pogrebal'nye kompleksy. Khronologiia i periodizatsiia). Barnaul, AltGTU Publ., 2010, 238 p. (In Russian)

Shul'ga P. I. Snariazhenie verkhovoi loshadi i voinskie poiasa na Altae. Chast'I. Ranneskifskoe vremia. Barnaul, Azbuka Publ., 2008, 276 p. (In Russian)

Tishkin A. A. Nakhodki nekotorykh elementov konskogo snariazheniia skifskoi epokhi v predgornoi zone Altaia. Snariazhenie verkhovogo konia na Altae v rannem zheleznom veke i srednevekov'e. Eds Iu. F. Kiriushin, A. A. Tishkin. Barnaul, Altai State University Press, 1998, pp. 78-90. (In Russian)

Val'chak S. B. Khronologiia Chernogorovskogo etapa (po materialam uzdechnykh naborov). Tezisy dokladov mezhdunarodnoi konferentsii «Problemy skifo-sarmatskoi arkheologii Severnogo Prichernomor'ia» posviashch. 95-letiiu so dnia rozhdeniia professora B. N. Grakova II. Ed. by G. N. Toshchev. Zaporozh'e, [S.n.], 1994, pp. 40-42. (In Russian)

Val'chak S.B. Udila predskifsogo perioda i kimmeriiskie loshadi Vostochnoi Evropy. Khar'kovskii istoriko-arkheologicheskii ezhegodnik "Drevnosti». Ed. by S. I. Posokhov. Khar'kov, AO "Biznes Inform" Publ., 1995, pp.44-47. (In Russian)

Val'chak S. B. Predmety epokhi pozdnei bronzy - rannego zheleza iz kollektsii Vostochnoi Ukrainy i ikh analogii. Arkheologichnii litopis Livoberezhnoï Ukraïni. Ch. 1-2. Eds O. B. Suprunenko, V.S. Andrienko. Poltava, Arkheologia Publ., 1998, pp. 19-22. (In Russian)

Val'chak S. B. Konskoe snariazhenie v pervoi treti I-go tys. do n. e.na iuge Vostochnoi Evropy. Moscow, Taus Publ., 2009, 291 p. (In Russian)

Vishnevskaia O. A. Kul'tura sakskikh plemen nizov'ev Syrdar'i v VII-V vv. do n.e. (po materialam Uigaraka). Moscow, Nauka Publ., 1973, 159 p. (In Russian)

Zaitseva G., Chugunov K. V., Alekseev A. Iu., Dergachev V. A., Vasil'ev S. S., Sementsov A. A., Kuk G. T., Skott E. M., Van der Plikht Kh., Bokovenko N. A., Kul'kova M. A., Burova N. D., Lebedeva L. M., Iunger Kh., Sonninen E. Istoriia i rezul'taty radiouglerodnogo datirovaniia kurgana Arzhan. Radiouglerod $v$ arkheologicheskikh i paleoekologicheskikh issledovaniiakh. (Materialy konferentsii, posviashchennoi 50-letiiu radiouglerodnoi laboratorii IIMK RAN, 9-12 aprelia 2007 g.). Eds G. I.Zaitseva, M. A. Kul'kova. St. Petersburg, IIMK RAN Publ., 2007, pp. 251-262. (In Russian)

Received: May 8, 2018 Accepted: September 10, 2018 